\title{
Examining the Relationship between Creativity and Critical Thinking through Integrated Problem-based Learning and Digital Mind Maps
}

\author{
Nurkhairo Hidayati ${ }^{1,2, *}$, Siti Zubaidah ${ }^{3}$, Endang Suarsini ${ }^{3}$, Henry Praherdhiono ${ }^{4}$ \\ ${ }^{1}$ Universitas Negeri Malang, Indonesia \\ ${ }^{2}$ Universitas Islam Riau, Indonesia \\ ${ }^{3}$ Department of Biology, Universitas Negeri Malang, Indonesia \\ ${ }^{4}$ Department of Educational Technology, Universitas Negeri Malang, Indonesia
}

Received July 9, 2019; Revised September 9, 2019; Accepted September 16, 2019

Copyright $\odot 2019$ by authors, all rights reserved. Authors agree that this article remains permanently open access under the terms of the Creative Commons Attribution License 4.0 International License

\begin{abstract}
Critical thinking is a complex process which requires higher-order thinking to achieve the expected outcome, while creativity is strongly associated with the production of useful and unique ideas. Both creativity and critical thinking involve new perspectives which can be empowered through the implementation of integrated Problem-based Learning (PBL) and Digital Mind Maps (DMM). The present study attempted to examine the relationship between critical thinking and creativity through the implementation of the combined PBL and DMM learning model in Human Physiology and Anatomy classes. This study employed a quasi-experimental design which involved students from the Department of Biology Education, Universitas Islam Riau, Indonesia. Every aspect of the participants' critical thinking and creativity was measured using an essay test. To reveal the relationship between critical thinking and creativity, a regression analysis was performed. The results showed that there was a significant relationship between critical thinking and creativity $(\mathrm{Y}=35.439+0.485 \mathrm{x})$. It, thus, can be concluded that the Integrated PBL and DMM model can be used as an alternative approach for simultaneous empowerment of students' critical thinking and creativity
\end{abstract}

Keywords Critical Thinking, Creativity, Integrated PBL-DMM

\section{Introduction}

Creativity can be defined in a few ways through cognitive processes, personality traits, environment variables, and an interaction between these components
(Kaufman, Quilty, Grazioplene, Hirsh, Peterson, \& DeYoung, 2016; Sternberg, 2006). Creativity can also be associated with discovering a fresh and original solution to one existing problem (Cropley, 2001) or producing new problem-solving ideas (Duff, Kurczek, Rubin, Cohen \& Tranel, 2013; Crilly, 2015; Lewis, 2005; Smith, 2014). Creativity, thus, can help someone deal with unexpected difficult circumstances. Creativity normally emerges during the process of finding advanced solutions (Cropley, 2001; Plucker, Beghetto, \& Dow, 2004; Reiter-Palmon, Illies, Cross, Buboltz \& Nimps, 2009) to complex social issues (Crilly, 2015).

Creativity is affected by problems identification and definition (Mumford, 2003). Creative people are sensitive to the existence of problems. They believe that without problems, individuals have little chance to show their creative traits (Kaufman et al., 2016). Runco \& Jaeger (2012) emphasizes that creativity is very helpful for solving problems. Lemon (2011) also notes that recognizing, discovering, and being aware of problems to find solutions are the characteristics of creativity. In the process of finding new solutions to problems, critical thinking is needed so that it can be said that creativity also includes cognitive activities such as critical thinking (Feldhusen \& Goh, 1995).

Critical thinking is a complex process that requires high-level reasoning to achieve desired results (Almeida \& Franco, 2011; Halpern, 2006). Different skills are involved in critical thinking. Critical thinkers constantly question the source of knowledge information, test the validity of the information, analyze the reliability of the information, and therefore are able to provide precise explanations on specific tasks or situations (Bruine, Fischhoff, \& Parker, 2007; Halpern, 2014; Hong \& Choi, 2015). Critical 
thinking can be considered as a multidimensional cognitive construction that implies the interaction between inductive and deductive reasoning and creative processes in different phases of problem-solving (Linn, 2000; Philley, 2005). In this way, critical thinking consists of cognitive, dispositional, motivational, behavioral, and metacognitive functions (Miele \& Wigfield, 2014).

In general, creativity and critical thinking include new perspectives, rather than being bound by rules or just looking for something ordinary and not genuine. They cannot be separated completely or considered as two different things. They sometimes complement each other (Spuzi et al., 2016) because the creative process is likely to involve several aspects of critical thinking (Villalba, 2017). Analysis, judgment, logical decision making and problem-solving are needed for critical thinking while creativity produces original ideas and finds new solutions. The way someone looks at a problem from different perspectives can affect his/her creativity (Vernon \& Hocking, 2014).

The tendency of being creative is to produce original ideas, views, and perspectives to solve problems, while critical thinking puts more focus on generating logical ideas, views and perspectives to solve problems. Yang \& Lin (2004) explain that critical thinking involves not only logic but also creative aspects. In fact, creative and critical thinking develop simultaneously (Chang, Bei-DiLi, Chen, \& Chiu, 2015 2015). On the other hand, Spuzic et al. (2016) argue that sometimes creativity and critical thinking can be regarded as two completely opposite elements. Creativity is related to divergent ways of thinking while critical thinking is related to convergent ways of thinking. At the stage where creativity needs to exist, critical thinking can become an inhibitory factor that reduces creativity because, in the creative process, a large number of ideas are needed. The interference of critical thinking may lead to decreasing the effectiveness of this divergent way of thinking because critical thinking emphasizes more on narrowing ideas and sharpening analysis.

Critical thinking and creativity are important for university students. Critical thinking can help learners make decisions (Butler, Pentoney \& Bong, 2017), adapt to changes (Alper, 2010), and provide benefits for the community (Dwyer, 2017). Creativity plays a crucial role in producing imaginative thinkers (Yates \& Twigg, 2017) who are able to create innovations in various fields (Kuo, Burnard, McLellan, Cheng, \& Wu, 2017). Due to their importance, critical thinking and creativity should be empowered in the classroom by doing appropriate learning practices (Leggett, 2017), such as implementing active learning, known as Integrated PBLDMM (Integrated Problem-Based Learning and Digital Mind Maps).

Problem-based Learning (PBL) is an active learning model that uses problems as a stimulus. It facilitates student-centered learning where teachers play an important role as a facilitator. The problem-based learning process is carried out in groups and new information is obtained through independent learning (Barrow, Lyte, \& Butterworth, 2002; O’Grady et al., 2012). As an active learning model, PBL has been shown to be able to increase critical thinking (Kek \& Huijser, 2011; Mahmoud \& Mohamed, 2017) and creativity (Ulger, 2018; Zhou, 2015). PBL can be integrated with digital mind maps (DMM). Mind maps can be combined with active learning models. This integration can increase high order thinking (Zubaidah, Fuad, Mahanal, \& Suarsini, 2017). The integrated PBLDMM model helps students represent ideas using high-level thinking skills (Faste \& Lin, 2012). This learning model is expected to increase students' critical thinking and creativity.

The introduction provides an explanation of the importance of knowing the relationship between critical thinking and creativity. Some experts claim the complementary nature of critical thinking and creativity, while some others argue that critical thinking and creativity are completely opposite. Based on this explanation, the study aimed to examine the relationship between critical thinking and creativity in Integrated PBLDMM model.

\section{Literature Review}

\subsection{Critical Thinking}

The concept of critical thinking has been widely used in various fields so that there are many definitions of critical thinking. Critical thinking is the ability to think rationally and reflectively. Thus, it helps individuals decide on what to believe or do (Ennis, 2011) through intellectual processes in conceptualizing, applying, analyzing, synthesizing, and evaluating information (Scriven, 2003). Critical thinking involves high-level cognitive skills such as conceptualization, analysis, and evaluation. In addition, critical thinking is also related to an intellectually open attitude that leads to logical and appropriate actions (Papp et al., 2014).

Critical thinking is a transferable skill that can be learned independently. An appropriate curriculum and teaching method can accommodate the development of students' critical thinking (Kim, 2009). Moreover, critical thinking can be set as a learning objective so that students learn to apply their cognitive skills (Dell'Olio \& Donk, 2007). The cognitive approach emphasizes the importance of mental processes in learning while paying attention to the surrounding environment (Schunk, 2008). This cognitive process can express concerns about developing key elements of students' thinking abilities such as analysis, induction, and evaluation (Adler, 2000).

Critical thinking is needed in everyday life (Ornstein, Pajak, \& Ornstein, 2011) as it can encourage a right and directed decision making, form opinions based on logical reasons, provide confidence in maintaining conclusions about what to do and receive correctly (Bassham, Irwin, 
Nardone, \& Wallace, 2011). The importance of critical thinking is also related to the actions taken. Critical thinking requires that we recognize assumptions that constitute the basis of our beliefs and behavior. In other words, we can provide justification for the ideas and conducts that we perform (Spuzic et al., 2016).

\subsection{Creativity}

Creativity can be defined in various ways, which involve cognitive processes, personality characteristics, and environment variables, as well as interactions between these components (Kaufman et al., 2008; Sternberg, 2006), related to the originality, novelty, and usability of ideas (Beghetto, Dow, \& Plucker, 2004; Runco \& Garrett, 2012). Creativity deals with divergent thinking that involves the interaction between abilities and processes when a person or a group of people produces a new and useful outcome or product (Leggett, 2017) based on one's knowledge, motivation, emotions, and experience (Runco \& Jaeger, 2012). The process of producing something new in creativity is driven by curiosity through the exploration to identify problems, observation, and investigation to find out how the creative predecessors invented breakthroughs (Starko, 2013).

The important role of creativity in the success of students has been reported by scholars (Butler et al., 2012; Runco et al., 2010). Creativity influences a person's success in the future (Castillo-vergara et al., 2018). Creativity equips someone with the ability to create innovations in various fields (Kuo, Burnard, McLellan, Cheng, \& Wu, 2017). Creativity is more than just a cognitive function because it occurs in a system with the involvement of many parties such as students' interaction with educators, peers, and other people and with other things or ideas (Jackson, 2016).

\subsection{The Integrated PBLDMM Model}

Problem-based Learning (PBL) is a learning model that facilitates group learning by providing a complex and meaningful set of problems for students so that they are able to gain scientific knowledge by solving these problems (Arends, 2012; Savery 2006). The problems raised are in accordance with real-life situations so as to encourage students to learn passionately and use inquiry-based learning skills (EL-Shaer \& Gaber, 2014; Carriger, 2015). In general, the learning process that takes place in a PBL classroom is formulating problems, finding references to solve the problems and conveying or reporting findings/solutions to the problems (Arends, 2012; Loyens, Kirschner, \& Paas, 2012).

The combination of PBL and Digital Mind Maps (DMM) can boost students' active participation. It also accommodates creative problem-solving (Noonan, 2013). Students are better prepared to face learning because they already have material provisions when compiling the DMM (Jbeili, 2013). DMM are created using a technology-based application. DMM help students compose their ideas (Faste \& Lin, 2012). The main idea is usually put in the middle and there are several branches of the map used to describe the details (Simonova, 2015). Images or videos can be added to the DMM to facilitate understanding (Papushina, Maksimenkova, \& Kolomiets, 2017).

\section{Methodology}

\subsection{Research Design}

This correlational study was conducted to examine the relationship between creativity and creative thinking through the implementation of Integrated Problem-Based Learning and Digital Mind Maps (Integrated PBLDMM). The stages of learning consisted of (1) students organized DMM to connect concepts, (2) students were introduced to problems, (3) students were organized to learn, (4) students were guided to learn as an individual and as a group member, (5) students were asked to present the results of the group discussion, (6) students were asked to do reflection and evaluation on learning. The stages of learning were performed to students from the Department of Biology who were studying Human Anatomy and Physiology.

\subsection{Research Instruments}

The instrument used to measure students' creativity was an essay test provided with an assessment rubric adapted from Greenstein (2012). The indicators of creativity measured were originality, elaboration, fluency, flexibility, risk-taking. The validity and reliability of the test had been confirmed beforehand and the results showed that the test was valid and reliable (0.84). In a similar way, another essay test was developed to examine the students' critical thinking. The test measured six aspects of critical thinking suggested by Ennis (2011) that are basic clarification, bases for a decision, inference, advanced clarification, supposition and integration, strategies and tactic. A validity test was performed and the result showed that the critical thinking test was valid and reliable (0.75).

\subsection{Data Collection and Data Analysis}

Data on the students' creativity and critical thinking data were collected by calculating the test scores. Before conducting the correlational analysis, the normality and homogeneity of the data were tested. The results showed that the critical thinking data were distributed normally (p-value of 0.200 and 0.097) and homogeneous (p-value of 0.177 and 0.055 ). Data on the students' creativity also had normal distribution (0.079 and 0.00) and were homogeneous (0.658 and 0.300 ). To see whether there was a significant correlation between creativity and critical thinking, Pearson Product Moment Coefficient of 
Correlation and analysis of regression were run. The relationship between the two variables was also analyzed descriptively.

\section{Results and Findings}

The results of the regression analysis on the relationship between critical thinking and creativity are presented in Table 1.

Table 1. The Results of the Regression Analysis

\begin{tabular}{|c|c|c|c|c|c|c|}
\hline & \multirow{2}{*}{ Model } & \multicolumn{2}{|c|}{$\begin{array}{c}\text { Non-standardized } \\
\text { Coefficients }\end{array}$} & \multirow{2}{*}{$\begin{array}{c}\begin{array}{c}\text { Standardized } \\
\text { Coefficients }\end{array} \\
\text { Beta }\end{array}$} & \multirow{2}{*}{$\mathbf{t}$} & \multirow{2}{*}{ Sig. } \\
\hline & & B & $\begin{array}{l}\text { Std. } \\
\text { Error }\end{array}$ & & & \\
\hline \multirow[t]{2}{*}{1} & (Constant) & 35.439 & 8.003 & & 4.428 & .000 \\
\hline & $\begin{array}{l}\text { Posttest } \\
\text { critical } \\
\text { thinking }\end{array}$ & .485 & .137 & .526 & 3.551 & .001 \\
\hline
\end{tabular}

Table 1 shows a constant value of 35.439 for creativity and 0.485 for critical thinking, hence the linear function that can depict the relationship between these two variables is:

$$
Y=35.439+0.485 x
$$

The functional form describes that creativity increases 0.485 with each additional point of critical thinking. Then, it can be interpreted that the improvement of students' critical thinking is followed by the development of their creativity.

To find out the significance of each regression coefficient, the t-test was carried out with a level of accuracy $(\alpha)$ of $5 \%$. The results of the t-test calculation can be seen in Table 1 in the right column. Based on Table 1, it is known that the regression equation is significant with $\mathrm{p}$-value $=0.001<\alpha(\alpha=0.05)$ and a coefficient of 0.485. A clearer distribution for each variable is presented in Figure 1.

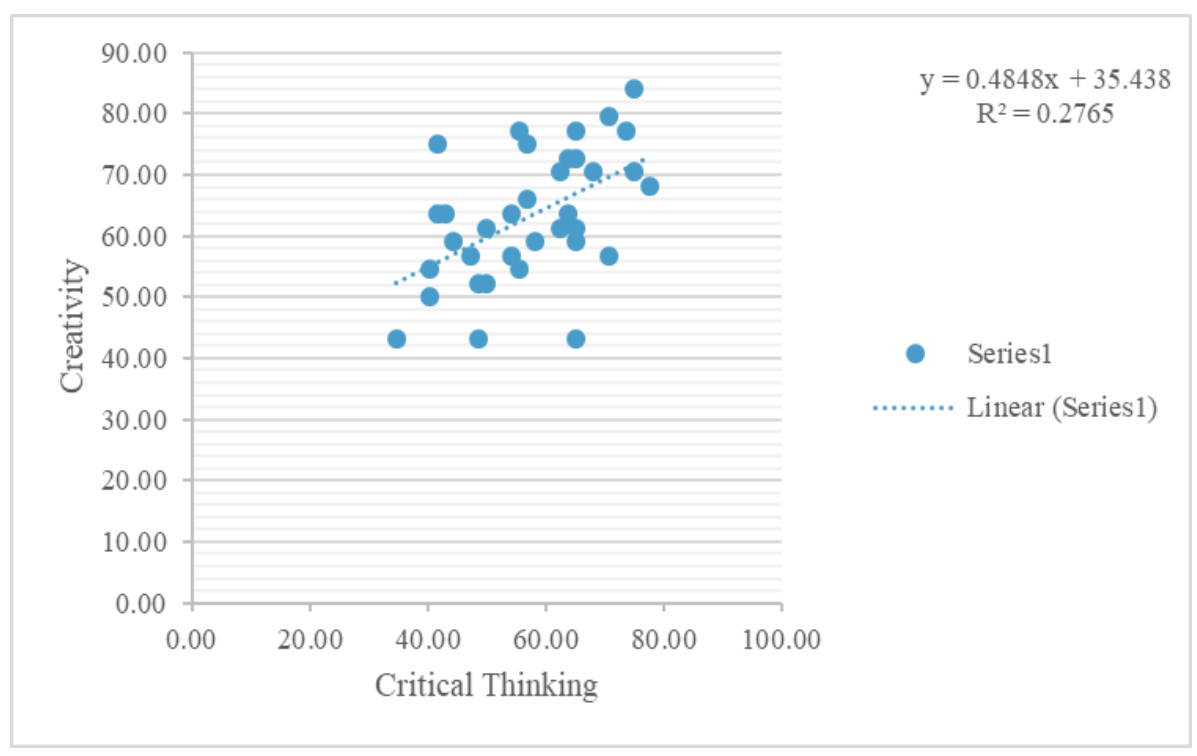

Figure 1. A Simple Linear Regression Plot

Table 2. The Results of the F-test

\begin{tabular}{cccccc}
\hline & Model & Sum of Squares & Mean Square & F & Sig. \\
\hline 1 & Regression & 1077.068 & 1077.068 & 12.608 & $.001^{\text {b }}$ \\
\hline Residual & 2818.998 & 85.424 & & \\
\hline Total & 3896.065 & & & \\
\hline
\end{tabular}

a. Dependent Variable: Post-test creativity

b. Predictor: (Constant), Post-test critical thinking 
The correlation between the independent variable and dependent variable was examined using F-test with a level of accuracy $(\alpha)$ of $5 \%$. The results of the F-test are presented in Table 2.

Table 2 shows that the relationship between critical thinking and creativity is significant, with $\mathrm{F}_{\text {calculated }}=$ 12.608 and $p$-value $=0.001<\alpha(\alpha=0.05)$. In other words, the linear regression function can be used to predict students' creativity scores.

The results of the analyses that have been presented earlier show that students' critical thinking increases as their creativity increases. The simultaneous development of the two variables may be facilitated by the Integrated PBLDMM used in the learning process. The first stage of PBLDMM which is the organization of digital mind maps (DMM) encourages students to read the material before coming to the classroom. It allows students to keep all important concepts in the DMM. During this process, students are allowed to improve their critical thinking by searching for important information from various references and sorting the information into the digital mind maps. In the process of creating an interesting and understandable digital mind map, creativity is required. Students need to be careful in choosing appropriate images that can represent concepts. This task entails thinking rather than just information memorization (Papushina et al., 2017). Paradice et al (2000) also add that critical thinking and creativity can form a single process where students are able to produce more ideas and filter information to make the right decision.

The results of this study are also in line with Villalba (2017) and Lipman (2003) who argue that creative solutions can be generated through evaluation stages that require critical thinking. On the other hand, Halpern (2006) explains that even though critical thinking and creativity can complement each other, they can be developed separately using varied learning strategies. However, this study has revealed that Integrated Problem-based Learning and Digital Mind Maps (PBLDMM) is able to improve students' critical thinking and creativity at once.

The relationship between critical thinking and creativity can also be inferred from the answers given by students while working on the critical thinking and creativity tests (Figure 2). In the critical thinking test, one student explained that hemodialysis can cause anemia and osteoporosis. The same student, in the creativity test, wrote that kidney transplant was a better solution for patients with kidney failure rather than hemodialysis. Students who were able to do the critical thinking test was also able to complete the creativity test perfectly. This shows that a critical thinker can make a logical connection between ideas derived from creativity (Marrapodi, 2003).

There is a significant correlation between critical thinking and creativity because creativity contains the elements of critical thinking. These two variables support each other. Critical thinking is used in evaluation and creativity is used in information synthesis. The evaluation focuses on making judgments based on statement analysis while synthesis concentrates on integrating parts and relationships in a new and original way (Huitt, 2003; Fairweather \& Cramond, 2010). One of the aspects of critical thinking is bases for a decision. The finding of this study suggests that students are able to make a better decision when they have various ideas or in other words when they possess creativity. It, thus, can be concluded that students' creativity can provide a basis for their creative thinking.

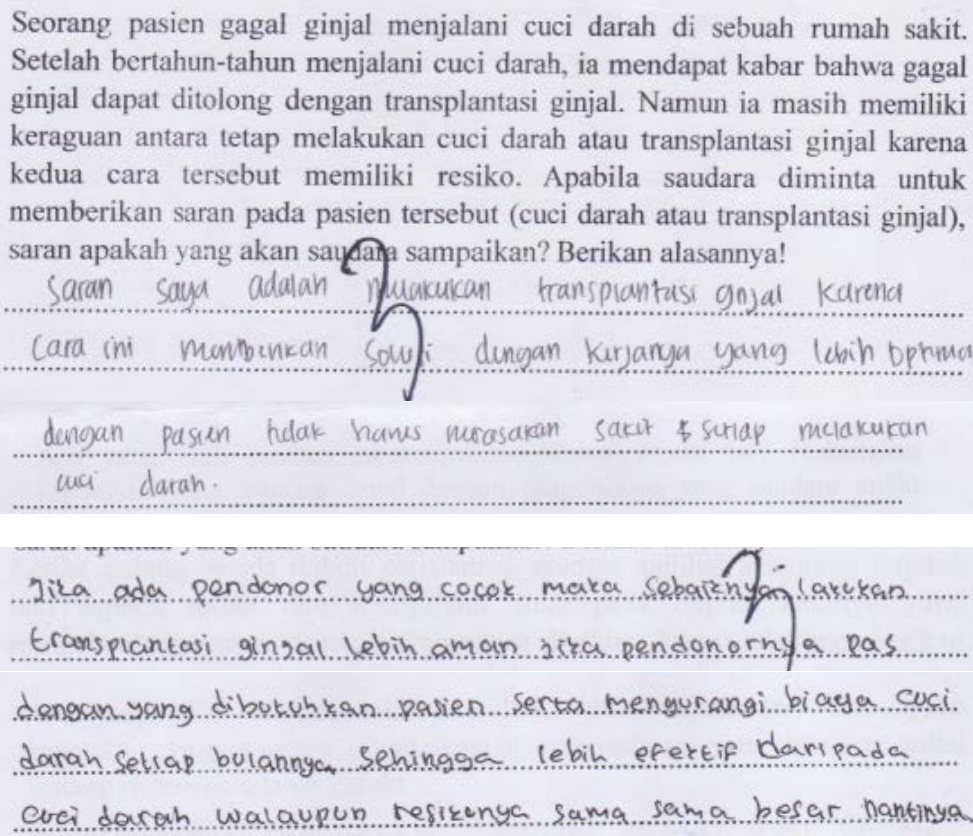



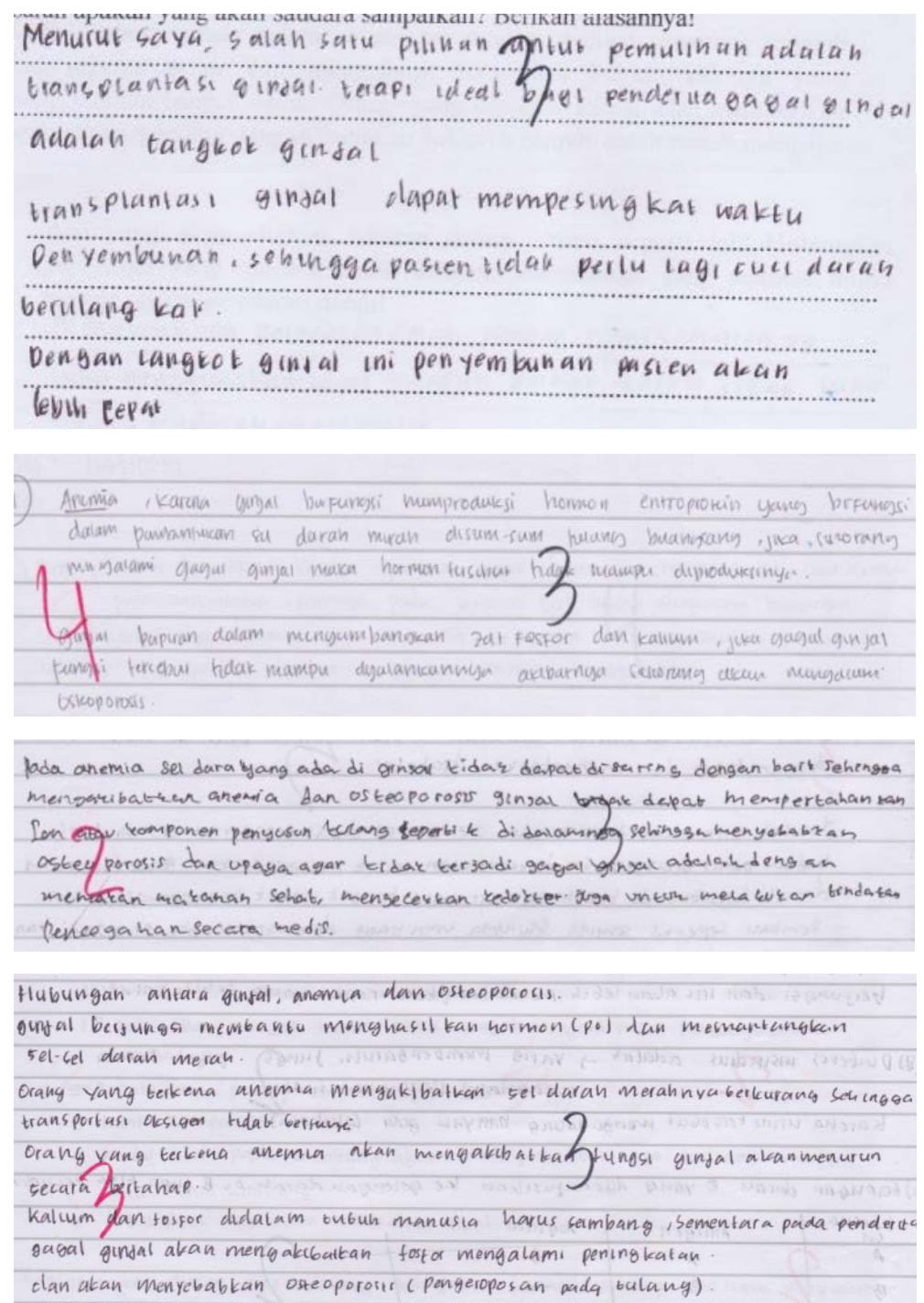

Figure 2. The Example of Student Answers

The process of achieving creativity involves deductive and inductive thinking which constitute parts of critical thinking. Wechsler (2012) explains that to produce new insights and solutions, problem-solving strategies and high-level thinking skills such as critical thinking are needed. The findings of this study indicate that students who are able to understand relationships between concepts and see them from different perspectives also have better critical thinking. The ability to connect concepts in order to find unique answers is an important characteristic of creative thinking (Hong \& Choi, 2015).

The relationship between critical thinking and creativity through the Integrated PBLDMM model that has been carried out in this study implies that these two skills can be empowered simultaneously in the classroom. While creativity is needed to produce new ideas, critical thinking plays an important role in sorting out the alternatives so that the most appropriate solution can be found to solve the issue. The synergy of these two skills (critical thinking and creativity) is a quality that students need to possess to embark on a career.

\section{Conclusions}

The results of the study showed that there was a significant correlation between critical thinking and creativity when Digital Mind Maps were integrated into Problem-based Learning. In addition, it was also found that both variables could be empowered simultaneously in the classroom and thus concurrent evaluation could be performed to both critical thinking and creativity. It is highly recommended for future researchers to consider other variables that may also affect the development of students' critical thinking and creativity.

\section{Acknowledgements}

This research was supported by the Educational Fund 
Management Institution (LPDP), the Ministry of Finance of Indonesia with number FR2712018124893

\section{REFERENCES}

[1] Almeida, L. S., \& Franco, A. (2011). Critical thinking: Its relevance for education in a shifting society. Revista de Psicología, 29(1), 175-195

[2] Alper, A. (2010). Critical thinking disposition of pre-service teachers. Egitim ve Bilim, 35(158), 14.

[3] Arends, R.I. 2012. Learning to Teach. New York. McGraww-Hill

[4] Barrow, E. J., Lyte, G., \& Butterworth, T. (2002). An evaluation of problem-based learning in a nursing theory and practice module. Nurse Education in Practice, 2(1), 55-62.

[5] Bruine, B. W., Fischhoff, B., \& Parker, A. M. (2007). Individual differences in adult decision-making competence. Journal of Personality and Social Psychology, 92(5),938956. doi.org/10.1037/0022-3514.92.5.938

[6] Butler, H. A., Pentoney, C., \& Bong, M. P. (2017). Predicting real-world outcomes: Critical thinking ability is a better predictor of life decisions than intelligence. Thinking Skills and Creativity, 25(July 2016), 38-46. https://doi.org/10.1016/j.tsc.2017.06.005

[7] Carriger, M. S. (2015). Problem-based learning and management development - Empirical and theoretical considerations. International Journal of Management Education, 13(3), 249-259. https://doi.org/10.1016/j.ijme. 2015.07.003

[8] Castillo-vergara, M., Galleguillos, N. B., Cuello, L. J., Alvarez-marin, A., \& Acuña-opazo, C. (2018). Does socioeconomic status influencee studentcreativity?? Thinking Skills and Creativity, 29(February), 142-152. https://doi.org/10.1016/j.tsc.2018.07.005

[9] Chang, Y., Bei-DiLi, Chen, H.-C., \& Chiu, F-C. (2015). Investigating the synergy of critical thinking and creative thinking in the course of integrated activity in Taiwan, Educational Psychology. International Journal of Experimental Educational Psychology, 35(3): 341-360. doi: 10.1080/01443410.2014.920079.

[10] Crilly, N. 2015. Fixation and creativity in concept development: The attitudes and practices of expert designers. Design Studies, 38 (2015): $54-91$ doi.org/10.1016/j.destud.2015.01.002

[11] Cropley, A. (2001). Creativity in education-learning. London: Kogan Page.

[12] Dell'Olio, J. M., \& Donk, T. (2007). Models of teaching: Connecting student learning with standards. Sage Publications.

[13] Duff, M. C., Kurczek, J., Rubin, R., Cohen, N. J., \& Tranel, D. (2013). Hippocampal Amnesia Disrupts Creative Thinking. Hippocampus, 23(12), 1143-1149. Retrieved from http://onlinelibrary.wiley.com
[14] Dwyer, C.P. (2017). To teach or not to teach critical thinking: A reply to Hubner and Kuncel. Thinking Skills and Creativity, 26, 92-95.

[15] EL-Shaer, A., \& Gaber, H. (2014). Impact of Problem-Based Learning on Student Critical Thinking Dispositions, Knowledge Acquisitio, and Retention. Journal of Education and Practice, 5(14), 74-85.

[16] Ennis, R.H. (2011). The Nature of Critical Thinking: An Outline of Critical Thinking Dispositions and Abilities. Retrieved from http://faculty.education.illinois.edurhennis/ documents. TheNatureofCriticalThinking_51711_000.pd

[17] Fairweather, E., \& Cramond, B. (2010). Infusing creative and critical thinking into the curriculum together. Nurturing creativity in the classroom, 113-141.

[18] Faste, H., \& Lin, H. (2012). The untapped promise of digital mind maps. In Proceedings of the SIGCHI Conference on Human Factors in Computing Systems (pp. 1017-1026). ACM.

[19] Feldhusen, J. F., \& Goh, B. E. (1995). Assessing and accessing creativity: An integrative review of theory, research, and development. Doi: 10.1207/s15326934crj0803_3.

[20] Greenstein, L. 2012. Assesing $21^{\text {st }}$ Century Skills: A Guide to Evaluating Mastery and Authentic Learning. United Kingdom: Sage Publication Ltd

[21] Halpern, D. F. (2014). Critical thinking across the curriculum: A brief edition of thought \& knowledge. Routledge.

[22] Hong, Y. C., \& Choi, I. (2015). Assessing reflective thinking in solving design problems: The development of a questionnaire. British Journal of Educational Technology, 46(4), 848-863. doi.org/10.1111/bjet.12181

[23] Huitt, W. (2003). The information processing approach to cognition. Educational psychology interactive, 3(2), 53.

[24] Jackson, N. J. (2016). Exploring creative pedagogies \& learning ecologies. Creative Academic Magazine, 7 [www.creativeacademic.uk/uploads/1/3/5/4/.../dis-cussion_ paper.pdf].

[25] Jbeili, I. M. A. (2013). The Impact of Digital Mind Maps on Science Achievement among Sixth Grade Students in Saudi Arabia. Procedia - Social and Behavioral Sciences, 103, 1078-1087. https://doi.org/10.1016/j.sbspro.2013.10.435

[26] Kaufman, S. B., Quilty, L., Grazioplene, R., Hirsh, J., Peterson, J., \& DeYoung, C. (2016). Openness to experience and intellect differentially predict creative achievement in the arts and sciences. Journal of Personality, 84(2), 248-258. doi: 10.1111/jopy.12156

[27] Kim, K., Sharma, P., Land, S. M., \& Furlong, K. P. (2013). Effects of Active Learning on Enhancing Student Critical Thinking in an Undergraduate General Science Course. Innovative Higher Education, 38(3), 223-235. https://doi.org/10.1007/s10755-012-9236-x

[28] Kek, M. Y. C. A., \& Huijser, H. (2011). The power of problem-based learning in developing critical thinking skills: Preparing students for tomorrow's digital futures in today's classrooms. Higher Education Research and Development, 30 (3), 329-341.https://doi.org/10.1080/072 


\subsection{0 .501074}

[29] Kuo, H.-C., Burnard, P., McLellan, R., Cheng, Y., \& Wu, J. (2017). The Development of Indicators for Creativity Education and a Questionnaire to Evaluate its Delivery and Practice. Thinking Skills and Creativity, 24, 186-198. https://doi.org/10.1016/j.tsc.2017.02.005

[30] Leggett, N. (2017). Early Childhood Creativity: Challenging Educators in Their Role to Intentionally Develop Creative Thinking in Children. Early Childhood Education Journal, 45(6), 845-853. doi:10.1007/s10643-016-0836-4

[31] Lewis, T. 2005. Creativity-A Framework for the Design/Problem Solving Discourse in Technology Education. Journal of Technology Education, 17(1) doi.org/10.21061/jte.v17i1.a.3

[32] Linn, M. C. (2000). Designing the knowledge integration environment. International Journal of Science Education, 22(8), 781-796. http://dx.doi.org/10.1080/0950069004122 75

[33] Lipman, M. (2003). Thinking in education. Cambridge University Press.

[34] Loyens, S. M. M., Kirschner, P. A., \& Paas, F. (2012). Problem-based learning. In K. R. Harris, S. Graham, \& T. Urdan (Eds.), APA educational psychology handbook (pp. 403-425). Washington, DC: American Psychological Association. http;//doi:10.1037/13275-016

[35] Mahmoud, A. S., \& Mohamed, H. A. (2017). Critical Thinking Disposition among Nurses Working in Puplic Hospitals at Port-Said Governorate. International Journal of Nursing Sciences, 4(2), 128-134. https://doi.org/10.1016/j.ijnss.2017.02.006

[36] Marrapodi, J. (2003). Critical thinking and creativity: An overview and comparison of the theories. Unpublished ED7590 Critical thinking and adult, Providence, RI.

[37] Miele, D., \& Wigfield, A. (2014). Quantitative and qualitative relations between motivation and critical analytic thinking. Educational Psychology Review, 26(4),519-541. http://dx.doi.org/10.1007/s10648-014-9282-2.

[38] Mumford, M. D. (2003). Where have we been, where are we going? Taking stock in creativity Research. Creativity Research Journal, 15(2\&3), 107-120. Doi:10.1080/10400419.2003.9651403.

[39] Noonan, M. (2012). Mind maps: Enhancing midwifery education. Nurse Education Today, 33(8), 847-852, http://dx.doi.org/10.1016/j.ned.2012.02.003

[40] O’Grady, G., Yew, E.H.J., Goh, K.P.L., Schmidt, H.G., 2012. One- Day, One-Problem. Springer Verlag.

[41] Ornstein, A.C., Pajak, E.F, \& Ornstein, S.B. (2011). Contemporary Issues in Curiculum (15th ed). Boston. MA: Pearson

[42] Papp, K. K., Huang, G. C., Lauzon Clabo, L. M., Delva, D., Fischer, M., Konopasek, L., Gusic, M. (2014). Milestones of critical thinking: A developmental model for medicine and nursing. Academic Medicine, 89(5), 715-720. https://doi.org/10.1097/ACM.0000000000000220

[43] Papushina, I., Maksimenkova, O., \& Kolomiets, A. (2017).
Digital Educational Mind Maps: A Computer Supported Collaborative Learning Practice on Marketing Master Program. Interactive Collaborative Learning, 17-30. https://doi.org/10.1007/978-3-319-66471-2

[44] Plucker, J. A., Beghetto, R.A., \& Dow, G.T. (2004). Why isn't creativity more important to educational psychologists? Potentials, pitfalls, and future directions in creativity research. Educational Psychologist. 39(2), 83-96. doi: 10.1207/s15326985ep3902_1.

[45] Philley, J. (2005). Critical thinking concepts. Professional Safety, 50, 26-32.

[46] Reiter-Palmon, R., Illies, M. Y., Kobe Cross, L., Buboltz, C., \& Nimps, T. (2009). Creativity and domain specificity: The effect of task type on multiple indexes of creative problem-solving. Psychology of Aesthetics, Creativity, and the Arts, 3(2), 73.

[47] Runco, M. A. (2014). Creativity. (2nd Ed.) USA: Elsevier.

[48] Runco, M. A., \& Jaeger, G. J. (2012). The standard definition of creativity. Creativity Research Journal, 24, 92-96. http://dx.doi.org/10.1080/10400419.2012.650092.

[49] Savery, J.. (2006). Overview of problem-based learning:Definitions and Distinctions. Interdisciplinary Journal of Problem Based Learning, 1(1), 269-282. https://doi.org/10.7771/1541-5015.1002

[50] Scriven, M. (2003). Evaluation theory and metatheory. In International handbook of educational evaluation (pp. 15-30). Springer, Dordrecht.

[51] Simonova, I. (2015). E-learning in Mind Maps of Czech and Kazakhstan University Students. Procedia - Social and Behavioral Sciences, 171, 1229-1234. https://doi.org/10.1016/j.sbspro.2015.01.236

[52] Smith, C., Nerantzi, C and Middleton, A. 2014. Promoting Creativity in Learning and Teaching. Retrieve from www.iced2014.se/proceedings/1120_Smith.pd

[53] Spuzic, S., Narayanan, R., Abhary, K., Adriansen, H. K., Pignata, S., Uzunovic, F., \& Guang, X. (2016). The synergy of creativity and critical thinking in engineering design: The role of interdisciplinary augmentation and the fine arts. Technology in Society, 45, 1-7. doi:10.1016/j.techsoc.2015.11.005

[54] Starko, A. J. (2013). Creativity in the classroom schools of curious delight. New York: Routledge.

[55] Sternberg, R. (2006). The nature of creativity. Creativity Research Journal, 18(1), 87- $98 . \quad$ doi: 10.1207/s15326934crj1801_10

[56] Ulger, K. (2018). The Effect of Problem-Based Learning on the Creative Thinking and Critical Thinking Disposition of Students in Visual Arts. Interdisciplinary Journal of Problem-Based Learning, 12(1), 3-6. Retrieved from doi.org/10.7771/1541-5015.1649

[57] Villalba, E. (2008). On creativity. Towards an Understanding of Creativity and its Measurements, JRC Scientific and Technical Reports, European Communities, Luxembourg.

[58] Villalba, E. (2017). Critical Thinking in Relation to Creativity. Center for the Development of Vocational 
Education and Training (Cedefop), Thessaloniki, Greece

[59] Vernon, D., \& Hocking, I. (2014). Thinking hats and good men: Structured techniques in a problem construction task. Thinking Skills and Creativity, 14, 41-46.

[60] Vong, S. A., \& Kaewurai, W. (2017). Instructional model development to enhance critical thinking and critical thinking teaching ability of trainee students at regional teaching training center in Takeo province, Cambodia. Kasetsart Journal of Social Sciences, 38(1), 88-95. https://doi.org/10.1016/j.kjss.2016.05.002

[61] Wechsler, S. M., Saiz, C., Rivas, S. F., Vendramini, C. M. M., Almeida, L. S., Mundim, M. C., \& Franco, A. (2018). Creative and critical thinking: Independent or overlapping components?. Thinking Skills and Creativity, 27, 114-122.

[62] Yang, S. C., \& Lin, W. C. (2004). The Relationship among Creative, Critical Thinking and Thinking Styles in Taiwan High School Students, Journal of Instructional Psychology, 31(1), 45-56.

[63] Yates, E., \& Twigg, E. (2017). Developing creativity in early childhood studies students. Thinking Skills and Creativity, 23, 42-57. https://doi.org/10.1016/j.tsc.2016.11.001

[64] Zhou, C. (2015). Bridging creativity and group by elements of Problem-Based Learning (PBL). In Pattern Analysis, Intelligent Security and the Internet of Things (pp. 1-9). Springer, Cham.

[65] Zubaidah, S., Fuad, N. M., Mahanal, S., \& Suarsini, E. (2017). Improving creative thinking skills of students through Differentiated Science Inquiry integrated with mind map. Journal of Turkish Science Education, 14(4), 77-91. https://doi.org/10.12973/tused.10214a 